\title{
Everolimus-induced interstitial pneumonitis in a kidney transplant recipients: A case report
}

\author{
Böbrek transplant alıcısında everolimusa bağlı interstisyel pnömoni: \\ Bir olgu raporu
}

Gulsah SASAK ${ }^{1}$, Ebru ZEMHERi ${ }^{2}$, Abdullah OZKOK ${ }^{1}$, Kubra AYDIN BAHAT ${ }^{1}$, Sabahat ALISIR ECDER ${ }^{1}$, Ali RIza ODABAS ${ }^{1}$

ABSTRACT

Use of serin-threonine kinase inhibitors, sirolimus and everolimus are recommended to decrease the potential development of chronic allograft nephropathy during chronic phase in renal transplant patients. Although these drugs have serious side effects such as proteinuria, edema, hyperlipidemia, impaired wound healing, mouth ulcers, anemia and proteinuria, among them the most important one is interstitial pneumonitis which is frequently related to sirolimus use. Hovewer, in the literature a few cases of everolimus-induced interstitial pneumonitis (EIP) have been reported recently. We wanted to revive this issue with this caase presentation under the light of current information. A 48year-old man was admitted with complaints of cough, fever and bloody sputum. He had living-donor kidney transplantation from his spouse 15 months ago. The etiology of end-stage renal disease was amyloidosis due to familial Mediterrenean fever. On physical examination, he had fever $\left(38^{\circ} \mathrm{C}\right)$, and bilateral basal fine crackles were detected. Everolimus was started 5 months ago because of the calcineurin inhibitor toxicity. He has also been on azathioprin, methylprednisolone and colchicine therapy. His remarkable laboratory findings were as follows: $\mathrm{Hg}: 7.8 \mathrm{~g} / \mathrm{dl}$, C-reactive protein: $4.5 \mathrm{mg} / \mathrm{l}$, and creatinine: $2.8 \mathrm{mg} / \mathrm{dl}$. Everolimus blood trough level was $4.2 \mathrm{ng} / \mathrm{ml}$. I On chest X-ray, bilateral interstitial infiltrates, reticular images and alveolar opacities were observed especially in the mid and lower zones. High-resolution pulmonary computedtomography revealed centri-acinar nodules with patchy areas of ground glass opacities in posterobasal segments of the both lungs being more pronounced in the right lower lobe, interlobar septal thickening and reticular lines in the adjacent pleural surfaces. Cultures of blood, urine, sputum and blood, were negative for cytomegalovirus and mycobacterium PCR. Hemosiderin laden macrophages were observed in his bronchoalveolar lavage. Then symptoms and signs of the patient were suggestively related to everolimus, and this drug was discontinued. Contrary to previous assumptions, everolimus can induce development of interstitial pneumonia, and alveolar hemorrhagia. Because of higher rates of mortality associated with this condition, the patients should be diagnosed, and treated at an early stage. This side effect of the drug should be kept in mind.

Key words: Everolimus, kidney transplantation, interstitial pneumonitis öz

Böbrek nakli olmuş olan hastalarda, kronik dönemde gelişebilecek allograft nefropatisi olasılığını azaltmak için serin treozin kinaz kullanılması önerilmektedir. Bu ilaçların da proteinüri, ödem, hiperlipidemi, bozulmuş yara iyileşmesi, ağızda yaralar, anemi, interstisyel pnömoni gibi yan etkileri vardır. Bu yan etkiler içerisinde en ciddi olanı, sıklıkla sirolimusa bağlı görülen interstisyel pnömonidir. Son zamanlarda, everolimusa bağlı gelișen interstisyel pnömoni vakaları da olgu sunumu olarak bildirilmektedir. Biz de bu vaka sunumu ile bu sorunu güncel bilgiler eşliğinde gündeme getirmek istedik. Kırk sekiz yaşındaki erkek hastaya 15 ay önce amiloidoza bağlı gelișen son dönem böbrek yetmezliği nedeniyle eşinden böbrek nakli yapıldı. Hasta daha sonra nefes darlığı, 38 derece ateş ve öksürük yakınmaları ile acil servise başvurdu. Muayenesinde bilateral ince ralleri olan hastaya kalsinörin toksisitesi nedeniyle 5 ay kadar önce everolimus kullanılmaya başlanmıştı. Bunun yanı sıra hasta azathioprin, kolşisin ve prednizolon da kullanmakta idi. Gerçeklestirilen laboratuvar tetkiklerinde hastanın hemoglobininin 7,8 g/dl, C-reaktif protein ölçümünün 4,5 mg/L ve kreatinin düzeyinin $2,8 \mathrm{mg} / \mathrm{dl}$ olduğu saptandı. Hastanın everolimus düzeyinin de $4,2 \mathrm{ng} / \mathrm{ml}$ olduğu görüldü. Hastanın çekilen PA AC grafisinde de her iki akciğerde infiltrasyon ve alveolar opasitelerin varlığı saptandı. Hastaya çekilen yüksek rezolüsyonlu AC tomografisinde ise sağda daha belirgin olmak üzere her iki akciğer alt lob posterobazal segmentlerde sentri-asiner nodüller ile birlikte yamasal buzlu cam alanları, interlober septal kalınlaşmalar ve komşu plevral yüzeylerde retiküler çizgilenmeler izlendi. Kan, idrar ve balgam kültürlerinde üreme olmadı. sitomegalovirus ve mikobakteri PCR negatifti. Hastaya bronkoalveolar lavaj sıvısında hemosiderin yüklü makrofajlar saptandı. Bunun üzerine hastanın semptom ve bulgularının everolimusa bağlı olabileceği düşüncesine varılarak ilaç kesildi. Takibinde hastanın semptomIarının hızla düzeldiği görüldü. Daha önce düşünülenin aksine, everolimusun interstisyel pnömoni ve alveolar hemorajiye neden olabilmektedir. Yüksek mortalitesi nedeni ile erken tanı konulup tedavi edilmelidir. Ilacın bu yan etkisinin akılda tutulması gereklidir.

Anahtar kelimeler: Everolimus, böbrek nakli, interstisyel pnömoni

Received: 02.02 .2016

Accepted: 19.04 .2016

${ }^{1}$ Department of Nephrology, Medeniyet University Goztepe Educational and Research Hospital, Istanbul, Turkey

${ }^{2}$ Department of Pathology, Medeniyet University Goztepe Educational and Research Hospital, Istanbul, Turkey

Yazışma adresi: Gulsah Sasak, Department of Nephrology, Medeniyet University Goztepe Educational and Research Hospital, Istanbul, Turkey

e-mail: gulsahsasak@gmail.com 


\section{GiRiş}

Serin-treozinkinaz inhibitörü olan sirolimus ve everolimus, organ nakillerinde kullanılan immünsüpresif ilaçlardır. Bu etkilerini T ve B lenfosit proliferasyonunu inhibe ederek gösterirler ${ }^{1}$. Kalsinörin inhibitörlerine bağı ıronik allograft nefropatisi riskini azaltmak için solid organ nakillerinde kullanımları giderek artmaktadır. Sirolimus ve everolimusun proteinüri, periferik ödem, hiperlipidemi, ağız ülseri, anemi gibi yan etkileri benzer olsa da interstisyel pnömoni daha çok sirolimusla ilişkili bulunmuştur ${ }^{2,3}$. Daha önceki yıllarda sirolimusa bağlı interstisyel pnömoninin tedavisinde, sirolimus yerine everolimus kullanılmış ve hastaların düzeldiği gözlemlenmiştir. Son yıllarda literatürde everolimusa bağı interstisyel pnömoni (EIP) vakalarının sıklığı giderek artmaktadır. Biz de bu vaka sunumu ile bu sorunu güncel bilgiler eşliğinde gündeme getirmek istedik.

\section{VAKA SUNUMU}

Kırk sekiz yaşında erkek hasta öksürük, ateş ve kanI balgam yakınmaları ile acile başvurdu. Yaklaşık 15 ay önce ailevi Akdeniz ateşine bağı ımiloidoz sonrası gelişen son dönem böbrek yetmezliği nedeni ile canlı donörden organ nakli operasyonu yapılmıştı. Kalsinörin inhibitör toksisitesi nedeniyle tedavisi 5 ay önce everolimus (1,5 mg/gün), azatiyoprin (100 $\mathrm{mg} / g u ̈ n$ ) ve metilprednizolon (4 $\mathrm{mg} / g u ̈ n)$ olacak şekilde düzenlenmişti. Özgeçmişinde 20 paket/yıl sigara hikayesi mevcuttu. Fizik muayenede ateş: $38^{\circ} \mathrm{C}$ idi ve her iki akciğer bazalinde bilateral ince raller mevcuttu. Laboratuvarında, hemoglobin: 7,8 g/dl, C-reaktif protein (CRP): $4,5 \mathrm{mg} / \mathrm{L}$, serum kreatinin: $2,8 \mathrm{mg} / \mathrm{dl}$ ve kan everolimus düzeyi: $4,2 \mathrm{ng} / \mathrm{ml}$ (hedeflenen kan düzeyi 4-8 ng/ml) idi. Akciğer grafisinde ise özellikle orta ve alt zonlarda bilateral interstisyel infiltratlar, retiküler görünüm ve alveoler opasiteler mevcuttu. Kan, idrar ve balgam kültürleri negatif idi. Ayrıca balgamda CMV ve mikobakteri PCR sonuçları negatif saptandı. Toraks tomografisinde; (Figür 1) sağda daha belirgin olmak üzere her iki akciğer alt lob posterobazal segmentlerde sentri-asiner nodüller ile birlikte yamasal buzlu cam alanları, interlober septal kalınlaşmalar ve komşu plevral yüzeylerde retiküler çizgilenmeler izlendi. Bunun üzerine hastaya bronkoskopi eşliğinde transbronşial biyopsi yapıldı. Patoloji sonucu interstisyel akciğer hastalığı ile uyumlu idi. Bronkoalveolar lavaj (BAL) sıvısında ise hemosiderin yüklü makrofajlar saptandı (Figür 2). BAL kültüründe Klebsiella üredi. Piperasilin-tazobaktam ve trimetoprim-sulfametaksazol ile antibiyotik tedavisi başlandı. Hastanın CRP düzeyi normale dönmesine rağmen, kliniğinde bir düzelme olmadı. Hastanın belirti ve bulgularının everolimusa bağlı olabileceği dü-

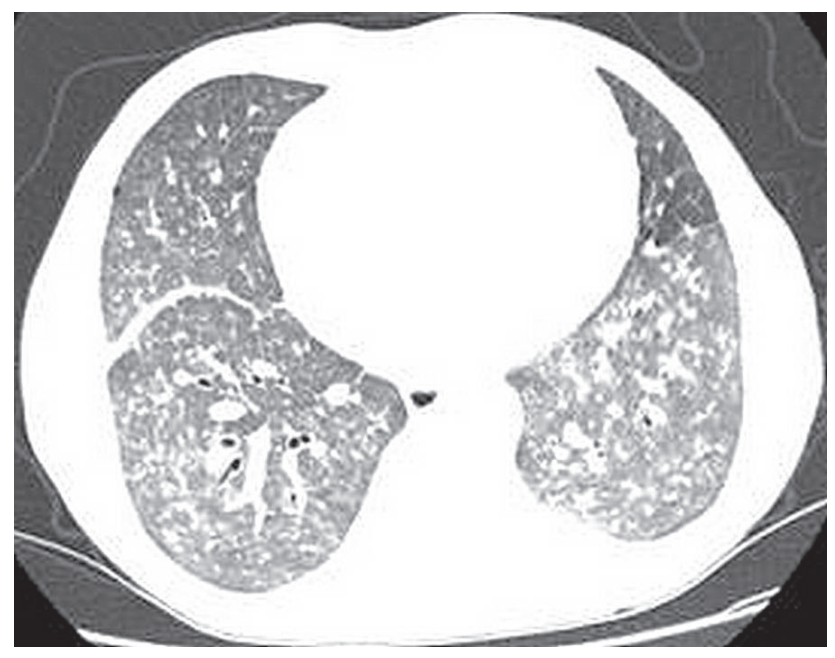

Figür 1. Sağda daha belirgin olmak üzere her iki akciğer alt lob posterobazal segmentlerde sentri-asiner nodüller ile birlikte yamasal buzlu cam alanları, interlober septal kalınlaşmalar ve komşu plevral yüzeylerde retiküler çizgilenmeler.

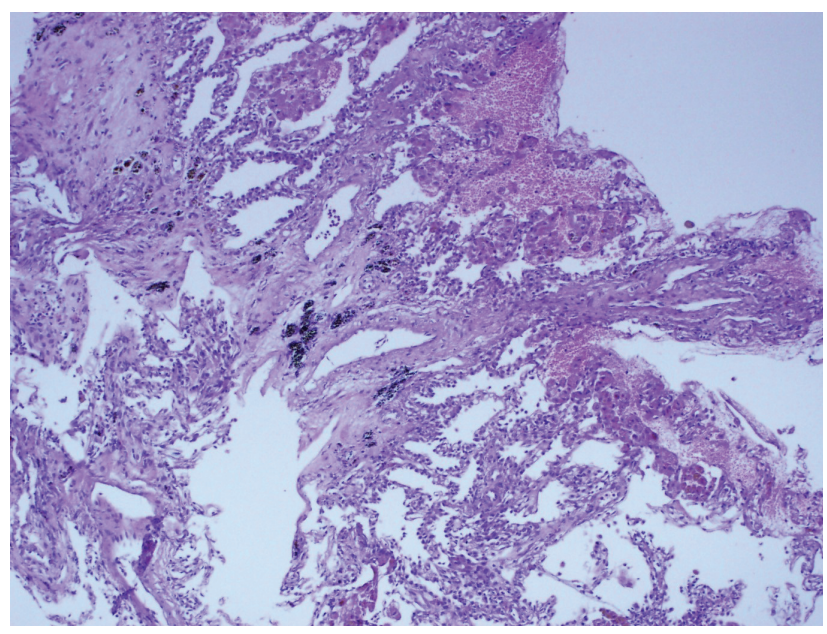

Figür 2. Alveol duvarlarında hafif fibröz doku artışı, hafif lenfosit infiltrasyonu, alveol lümenlerinde kanama ve hemosiderin yüklü makrofajlar (H\&Ex200). 
şünülerek everolimus kesilip takrolimusa geçildi ve almakta olduğu steroid dozu 16 mg/güne yükseltildi. Hastanın takibinde kliniği 1 ay içinde düzeldi ve 6 ay sonra çekilen toraks tomografisinde ise (Figür 3 ) bir önceki tomografisinde gözlenen yamasal buzlu cam alanlarında ve interstisyel işaretlerde belirgin regresyon izlendi.

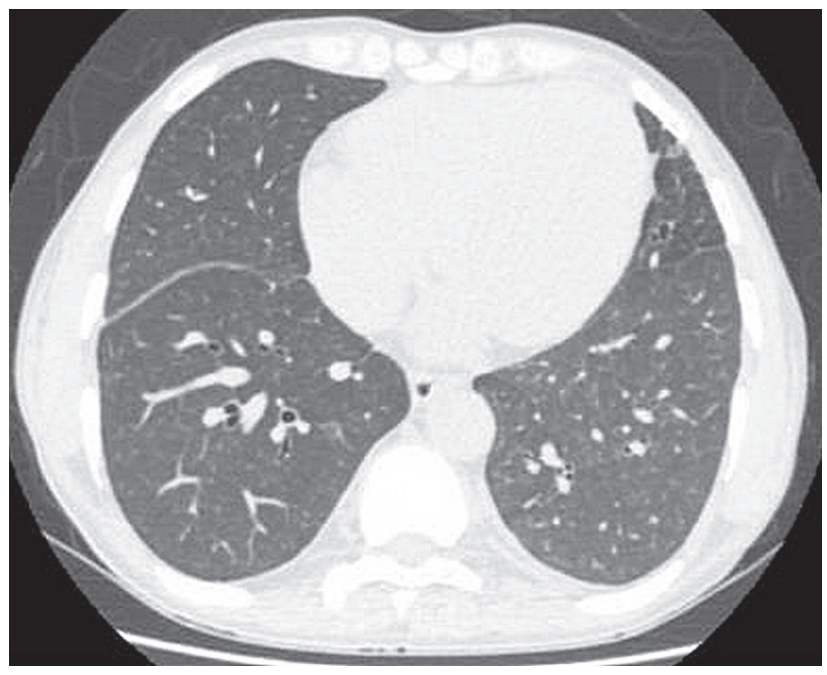

Figür 3. Bir önceki tomografisinde gözlenen yamasal buzlu cam alanlarında ve interstisyel işaretlerde belirgin regresyon izlendi.

\section{TARTIŞMA}

Interstisyel pnömoni, serin-treozin inhibitörlerinin en yüksek mortalite ve morbiditeye neden olan en önemli yan etkisidir. Böbrek nakilli hastalarda sirolimusa bağlı interstisyel pnömoni sıklığı \%4-11 arasında bildirilmiştir ${ }^{4}$. Pnömoniye bağlı mortalitenin insidansı ise yaklaşık olarak \% $5^{\prime}$ tir $^{5}$. Başlangıçta sirolimusa bağlı interstisyel pnömoninin tedavisinde everolimus alternatif ajan olarak düşünülmesine rağmen, EIP bildirilme sıklığı da giderek artmaktadır. Baas ve ark. ${ }^{6}$ EIP insidansını \%12,7 olarak bildirmiş fakat asemptomatik vakalar bu çalışmaya dahil edilmediği için gerçek oranın daha yüksek olabileceği iddia edilmiştir. Everolimus ile tedavi edilen renal karsinomalı hastalarda, periyodik toraks tomografisi takipleri sonucu EIP insidansının \%25 olduğu bildirilmiştir ${ }^{7}$.

Hastalığın kliniği asemptomatikten ciddi solunum yetmezliğine kadar değişebilir. Çoğu vakada akciğer röntgenogramlarında herhangi bir patoloji saptan- maz iken, yalnızca akciğer tomografilerinde patolojik değişiklikler saptanabilir. Tomografide sıklıkla görülen anormallikler buzlu cam manzarası, bronşiolitis obliterans ve periferik infiltrasyondur. Hastamızın kiliniğinde öksürük, balgam ve ateş vardı. İleri derecede solunum yetmezliği yoktu. Ayırıcı tanı ancak diğer sebepler dışlanarak yapılabilir.

mTOR inhibitörleri ile gelişen pnömoninin patogenezi tam olarak anlaşılamamıştır. İlaca bağlı direkt toksisite, immünolojik toksisite veya her ikisinin birlikte sorumlu olduğu ileri sürülmüştür. Hastaların akciğer biyopsilerinde lenfositik alveolitis, pulmoner hemoraji ve bronşiolitis obliterans en sık rastlanan histopatolojik bulgulardır ${ }^{8}$. Bu da hastalığın immünolojik patogenetik mekanizmasını destekler.

İlacın kesilmesini takiben kliniğin hızla düzelmesi ilaca bağlı direkt toksisiteyi desteklemektedir ${ }^{5}$. Sigara, akciğer hastalığı öyküsü ve böbrek yetmezliği etiyolojide suçlanan diğer nedenlerdir ${ }^{9}$. White ve ark.'nın ${ }^{10}$ yaptığı çalışmada, başlangıçtaki tomografilerinde altta yatan akciğer hastalığı olanlarda pnömoni insidansının daha yüksek olduğu görülmüştür. Baas ve ark. ${ }^{6}$ ise çalışmalarında bu ilişkiyi gösterememişlerdir. Şu ana kadar herhangi bir predispozan faktörün etkisi kesin olarak saptanamamıştır.

Hastamızda sigara içimi bir risk faktörü olarak vardı. Kan everolimus düzeyi normal sınırlar içindeydi. BAL sıvısında alveoler hemoraji saptandı. Alveolar hemorajiye neden olan diğer durumlardan toksik madde inhalasyonu öyküsü, koagülopati veya volüm fazlalığı yoktu. Hastanın yapılan ekokardiyografisinde sol ventrikül sistolik fonksiyonları normaldi. BAL kültüründe Klebsiella pneumonia üredi. Fakat klinik iyileşme antibiyotik tedavisi sonrası değil everolimus kesildikten sonra görüldü. Bu da ilaca bağlı interstisyel pnömoni tanısını desteklemektedir.

Özetle daha önce düşünülenin aksine, everolimus interstisyel akciğer hastalığı ve alveolar hemoraji gibi akciğer ile ilişkili komplikasyonlara daha sık neden olabilir. Organ nakli hastalarını takip eden klinisyenlerin bu mortalite ve morbiditesi yüksek komplikas- 
yonu her zaman göz önünde bulundurmaları gerekmektedir.

\section{KAYNAKLAR}

1. Sanchez-Fructuoso Al, Ruiz JC, Perez-Flores I et al. Comparative analysis of adverse events requiring suspension of mTOR inhibitors everolimus versus sirolimus. Transplant Proc 2010;42:3050-2. https://doi.org/10.1016/j.transproceed.2010.07.083

2. Weir MR, Diekmann F, Flechner SM et al. mTOR inhibition: the learning curve in kidney transplantation. Transpl Int 2010;23:447. https://doi.org/10.1111/j.1432-2277.2010.01051.x

3. Alexandru S, Ortiz A, Baldovi S et al. Severe everolimusassociated pneumonitis in renal transplant recipient. Nephrol Dial Transplant 2008;23:3353-5. https://doi.org/10.1093/ndt/gfn401

4. Weiner SM, Sellin L, Vonend O et al. Pneumonitis associated with sirolimus: clinical characteristics, risk factors and outcome-a single-center experience and review of the literature. Nephrol Dial Transplant 2007;22:3631-7. https://doi.org/10.1093/ndt/gfm420

5. Cravedi P, Ruggenenti P, Remuzzi G. Sirolimus for calcineu- rin inhibitors in organ transplantation: contra. Kidney Int 2010;78:1068-74. https://doi.org/10.1038/ki.2010.268

6. Baas M.C, Struijk G.H, Moes D.J et al. Interstitial pneumonitis caused by everolimus: a case-cohort study in renal transplant recipients. Transpl Int 2014;27:428-36. https://doi.org/10.1111/tri.12275

7. Tsukamoto T, Shinohara N, Tsuchiya $\mathrm{N}$ et al. Phase III trial of everolimus in metastatic renal cell carcinoma: subgroup analysis of Japanese patients from RECORD-1. Jpn J Clin Oncol 2011;41:17-24. https://doi.org/10.1093/jjco/hyq166

8. Kirby S, Satoskar A, Brodsky S et al. Histological spectrum of pulmonary manifestations in kidney transplant recipients on sirolimus inclusive immunosuppressive regimens. Diagn Pathol 2012;7:25. https://doi.org/10.1186/1746-1596-7-25

9. Molas-Ferrer G, Dolors SM, Anglada-Martinez $\mathrm{H}$ et al. Intertitial pneumonitis as an adverse reaction to mTOR inhibitors. Nefrologia 2013;33:297-300.

10. White DA, Schwartz LH, Dimitrijevic S et al. Characterization of pneumonitis in patients with advanced non-small cell lung cancer treated with everolimus (RAD001). J Thorac Oncol 2009;4:1357. https://doi.org/10.1097/JTO.0b013e3181ba20b1 